\title{
PAUL AND JOHN THE BAPTIST: AN ODD COUPLE?
}

\section{J. Ramsey Michaels}

Sometimes in the world of scholarship a mere title can be as thought-provoking as the book or article it represents. David P. Moessner, for example, titled his 1988 article 'Paul in Acts: Preacher of Eschatological Repentance to Israel. ${ }^{1}$ It occurred to me that this sounded more like John the Baptist than Paul as usually understood, and I wondered if perhaps Moessner might be drawing some comparisons between Paul's ministry and John's. This turned out not to be the case. The article had to do with parallels between Paul's pronouncements of judgment in the Book of Acts and those of Jesus in Luke's Gospel. Yet the notion of Paul as 'Preacher of Eschatological Repentance to Israel' set me thinking about Paul and John the Baptist. What could the two possibly have to do with each other? Culturally they lived in rather different worlds. Chronologically they were separated by the ministry of Jesus, his death and resurrection, and the coming of the Spirit. Paul never quotes or even mentions John in his letters. If Paul is relatively silent about the pre-resurrection ministry and sayings of Jesus of Nazareth (cf. only 1 Cor. 7:10-11, 9:14, 11:23-26, and possibly 1 Thes. 4:15), he is totally silent about the ministry and sayings of Jesus' predecessor.

This conclusion is based on Paul's letters, and everyone agrees that Paul's own writings are by far our best source for a knowledge of the Apostle's thought. Yet they are not quite our only source. Paul has many lines in the Book of Acts, including a number of speeches of varying length to varied audiences (e.g. Acts 13:16-41; 14:15-17; 17:22-31; 20:18-35; 22:3-21; 24:10-21; 26:2-23). It is commonly assumed that when we refer to these speeches attributed to Paul in Acts, we are actually speaking of 'Luke' (whoever he may have been) and his perspective, not of Paul himself. Many scholars assume this because they view

${ }^{1}$ NTS 34 (1988), 96-104. 
the speeches in Acts in their entirety as Luke's free compositions after the manner of Thucydides. Others speak vaguely of Luke's 'sources', yet are reluctant to attribute specific elements in the speeches to Peter, or Stephen, or Paul, or whoever is represented as the speaker on a particular occasion.

In general, such caution is well taken. We cannot be absolutely certain that Paul uttered any of the words attributed to him in Acts. Still, Paul twice makes explicit citations from some form of the Gospel tradition, ${ }^{2}$ and in neither case is he simply echoing the Gospel of Luke. Once he quotes Jesus (Acts 20:35), and once John the Baptist (Acts 13:25). The citation from Jesus ('It is more blessed to give than to receive') is not found in Luke or any other written Gospel, while the citation from John is distinctive in form from the record of John's teaching either in Mark, or the so-called ' $Q$ ' material, or material unique to Matthew or to Luke, or in the fourth Gospel. Whether these citations are attributed to 'Paul' or more cautiously to 'the Lukan Paul', they exhibit an independent use of Gospel tradition, and (in the case of John the Baptist) an interpretation of it which is not simply an echo of Luke's own.

\section{Paul's Citation of John (Acts 13:24-25)}

In his first synagogue sermon after the vision on the way to Damascus (Acts 13:16-41), 'Paul' (who is just beginning to be called by that name, v. 9) abruptly introduces John the Baptist into his summary of biblical history and the story of Jesus. Neither Peter nor Stephen had mentioned John in their early sermons to the Jews in Jerusalem. Peter, addressing Gentiles in the house of Cornelius in Acts 10, had referred to John once in passing in his summary of Jesus' ministry (10:37b, 'beginning from Galilee after the baptism which John preached', cf. also 1:21-22), and later in Jerusalem had referred to John once in a

\footnotetext{
${ }^{2}$ The only other possible citation from Gospel tradition is the pronouncement of the risen Jesus in Acts 1:5: 'John indeed baptised in water, but you will be baptized in the Holy Spirit'. It is difficult to say whether this saying is a citation (introduced by " $\tau \imath$, 'that') of something Jesus had said before the resurrection (i.e., 'the promise of the Father, which you heard from me', v. 4), or whether Jesus is now saying it for the first time (with on munderstood as 'because,' or 'for'). In either case, it is a 'word of the Lord' which Peter explicitly remembered after the Holy Spirit had come on the Gentiles (Acts 11:16).
} 
citation of 'the word of the Lord' (11:16; see n. 2). Paul's reference to John in the synagogue at Antioch in Pisidia is more substantial, to the extent of quoting John's own words (13:24-25).

Paul places the citation just after his summary of Jewish history (vv. 16-22) and brief introduction of Jesus as a Saviour descended from David (v. 23), and just before a dramatic appeal to his audience on the basis of Jesus' death and resurrection (vv. 26-31) with the supporting testimony of Jewish Scripture (vv. 32- 40). Paul introduces John as one who preached, before Jesus' coming, 'a baptism of repentance to all the people of Israel' (13:24). He then quotes John as saying, near the end of ministry when he was 'finishing his course', these words: 'I am not what you think I am. ${ }^{3}$ But there is one coming after me, the sandal of whose feet I am not worthy to untie' (v. 25). Paul then proceeds to his proclamation of Jesus in light of the Jewish Scriptures (vv. 26-31), reiterating in vv. 3240 the emphasis of v. 23 that Jesus is Israel's Messiah and Saviour. The implication is clear that 'the one coming after' John is Jesus, and that the Baptist's most significant role was to bear testimony to Jesus' coming.

This is the implication of the synoptic Gospels as well, especially Matthew and Mark, where John announces the 'Mightier One' to come, and Jesus immediately appears (Mt. 3:11-13//Mk 1:7-9). In Luke's Gospel, the connection is not quite so close. After the reference to the 'Mightier One' (Lk. 3:15-17), Luke concludes the story of John the Baptist with a final summary of John's ministry (v. 18) and a brief notice of his imprisonment by Herod Antipas (vv. 19-20). Only then is Jesus brought on the scene for baptism (vv. 21-22). Luke's account is consistent with that of the Lukan Paul in that John's disclaimer indeed comes as he was 'fulfilling his course'. It is the last

\footnotetext{
${ }^{3}$ Or, 'What do you think I am? I am not (he)' (F.F. Bruce, The Acts of the Apostles. The Greek Text with Introduction and Commentary, 3rd ed (Grand Rapids, Eerdmans 1990) 307). This construction might be preferable if the reading tiv $\alpha$, 'who,' were adopted (with P45, C, D, the Latin tradition, and the majority of later manuscripts) instead of $\boldsymbol{\tau}^{\prime}$, 'what,' (the reading of P74, $\boldsymbol{\tau} i$, $B, A$, and a number of other important manuscripts). As it is, the interrogative $\tau^{\prime}$ is probably being used as a relative pronoun, as, e.g., in Mt. 10:19, Mk 14:36, Lk. 17:8 (see F.Blass, A.Debrunner, R.W. Funk, A Greek Grammar of the New Testament and Other Early Christian Literature (Chicago, University of Chicago 1961) par. 298[4]).
} 
pronouncement attributed to him before his career comes to an end, and it is giv.en in response to the public's unspoken question 'whether he himself might possibly be the Christ' (v. 15b; cf. Jn. 1:19-22).

Yet Paul's quotation of the Baptist in Acts 13:25 is not dependent on Luke, or any other known Gospel. It agrees with John 1:26-27 against the synoptics in making no mention of 'the Mightier One', in using đ’k and in using the singular vं $\pi \delta \delta \eta \mu \alpha$, 'sandal', instead of the plural form common to Matthew, Mark, and Luke. ${ }^{4}$ It agrees with Matthew against Mark, Luke, and John in omitting tòv i $\mu \alpha^{\prime} v \tau \alpha$, 'the thong' (Mark and Luke have 'the thong of his sandals', while John's Gospel has 'the thong of whose sandal'). Yet Paul's citation has nothing else in common with Matthew's unique expression, 'whose sandals I am unworthy to carry'. It can only be regarded as a witness in its own right to the words of John the Baptist. ${ }^{5}$ Like Mark, and like the Fourth Gospel, the Lukan Paul in this text focuses John the Baptist's message entirely on the One 'who comes after me', identified unmistakably in the context as the 'Saviour Jesus' (v. 23). At the same time, Paul's mention of John's preaching of a 'baptism of repentance' (v. 24; cf. Mk 1:4//Lk. 3:3) and his placement of the saying about the coming one at the end of John's ministry stand as tacit acknowledgment that Jesus was not the sole theme of everything John said and did.

\section{Paul's Interpretation of John (Acts 19:4)}

The understanding of John the Baptist implicit in the sermon at Antioch of Pisidia becomes explicit later in Paul's encounter with twelve 'disciples' in Ephesus (Acts 19:1-7). When they claim to know nothing of the Holy Spirit, Paul asks them (v. 3), 'What baptism, then, have you received?' (cis $\tau^{\prime}$ oṽv $\dot{\varepsilon} \beta \alpha \pi-$

\footnotetext{
${ }^{4}$ Cf. C.H. Dodd, Historical Tradition in the Fourth Gospel (Cambridge, University Press 1963), 253-59.

${ }^{5}$ Dodd finds in this passage 'the use of a separate source,' which he believes is 'of a quite different character from those which are being used in Luke iii.' This source gave Luke 'some traditional authority for the statement that there was, if not a belief, at least the suggestion of a possibility, that John the Baptist might be the Messiah, and that he expressly repudiated it' (Historical Tradition, 257). Dodd does not attempt to identify this source more specifically, yet there is no denying that Luke, for his part, identified it as Paul.
} 
$\tau$ t $\sigma \theta \eta \tau \varepsilon$; lit., 'into what, then, were you baptized?'). Their

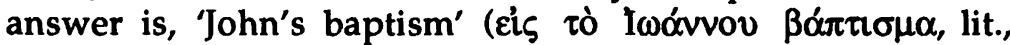
'into John's baptism'). This affords Paul an opportunity to speak of John again, this time without placing him in the context of an extended sermon: 'John baptized [with] a baptism of repentance, telling the people to believe in the one coming after him, that is, in Jesus' ${ }^{6}$ The phrase, 'baptism of repentance', recalls 13:24, Again, the pronouncement of the Lukan Paul raises the question of whether this is the voice of Luke, or of an unidentified Lukan source, or of Paul himself.

Without answering that question directly, F.F. Bruce calls attention to two similarities between Paul's estimate of John the Baptist in Acts 19:4 and the viewpoint of the Fourth Gospel: (1) 'That John directed his hearers to believe in the coming one is not explicitly stated by the Synoptists, but is in thorough accord with his testimony to Jesus in John 1:26f.; 3:2730 (cf. Jn. 1:7; 10:41)'; (2) 'In the Synoptic narrative John does not expressly identify the coming one with Jesus (he questions the identity in Lk. 7:19 par. Mt. 11:3). He makes this identification, however, in John 1:29-34. Some striking agreements between John and Acts in their presentation of John's ministry and of the Holy Spirit deserve careful study (see also on 13:25). ${ }^{7}$

Ernst Haenchen, by contrast, finds significant differences both from the synoptic and Johannine traditions. Acts 19:4 'goes beyond the synoptic tradition, in which John only proclaims the Coming One but does not summon to belief in him (which in the framework of his proclamation would have been meaningless). Neither is the Johannine tradition reproduced, in which John and Jesus work side by side. It should be borne in mind that our passage gives the final result of the Baptist's activity and significance, and is not narrating a detail from his life. ${ }^{\prime 8}$ Haenchen's comment implies that the

${ }^{6} \mathrm{Lit}$. 'speaking to the people about the One coming after him, that they should believe - that is, in Jesus.' The pronouncement is careful not to claim too much. Paul does not say that John told the people in so many words to believe in Jesus, nor even that he told them to believe in the Coming One. What Paul says is that John told the people about the Coming One, with the intent that they should believe, and that the Coming One turned out in fact to be Jesus.

${ }^{7}$ Bruce, op. cit., 407.

${ }^{8} \mathrm{E}$. Haenchen, The Acts of the Apostles: A Commentary (Oxford, Basil Blackwell, 1971), 553, n. 5. 
Lukan Paul's summary of 'the final result of the Baptist's activity and significance' is not Lukan, but an independent tradition. Yet Haenchen stops short of saying so explicitly, and consequently never pursues the question of the tradition's origin. Again, Luke would have us believe that it comes from Paul.

If a distinctly Pauline perspective on John the Baptist can be traced in the Book of Acts, it is one that agrees with the Synoptics against the Fourth Gospel that Jesus did not begin his ministry until John's was over. Yet at the same time, it goes beyond the Synoptics in claiming - with the Fourth Gospel that John explicitly identified his 'Coming One' with Jesus of Nazareth, and invited the people to believe in Jesus. In this respect the Lukan Paul stands midway between the Synoptic and Johannine traditions.

\section{Paul's Indebtedness to John (Acts 20:21; 26:20)}

Paul in the Book of Acts never mentions John the Baptist by name after 19:4. Yet his summaries of his own ministry echo in subtle ways the characteristics he had earlier assigned to John's ministry. In Acts 20:21, Paul is addressing 'the elders'

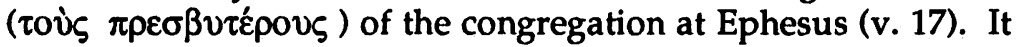
is difficult to say whether or not Luke intends us to identify these 'elders' with the group of 'about twelve' (19:7) for whom Paul had earlier interpreted John's ministry. ${ }^{9}$ Certainly the twelve were the first Ephesian converts to be singled out for special mention in Luke's narrative. In any case, Paul defines for them his own ministry as 'testifying both to Jews and Greeks repentance toward God and faith in our Lord Jesus' ( $\tau$ iv عis

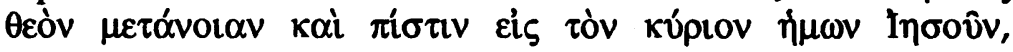
20:21).

The twin phrases, 'repentance toward God' and 'faith in our Lord Jesus', are significant both within the Lukan narrative as a whole and within Luke's presentation of Paul. Acts 20:21 accurately summarizes the ministry of Paul as Luke presents it. Paul's messages to Gentile audiences had indeed cen-

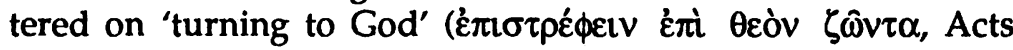

\footnotetext{
${ }^{9}$ Such an identification is implicit in comments like that of W. Neil, in The Acts of the Apostles (NCB London, Oliphants 1973): 'it has been suggested that the "twelve" here may point to the existence of a "college" of twelve, set up by Paul for the organization and government of the church at Ephesus' (203).
} 
14:15), and on God's command to everyone everywhere to

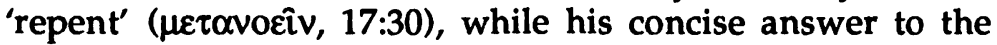
question of the jailer at Philippi ('What must I do to be saved?') was, 'Believe in the Lord Jesus Christ, and you will be saved, and your house' (16:30-31). This terminology in Acts cannot be classed as specifically 'Pauline', in distinction from 'Lukan', or even (generically) 'early Christian'. Jesus, near the beginning of Mark, had announced, "The time is fulfilled, and the kingdom of God is near; repent and believe in the gospel' (Mk 1:15). At the end of Luke's Gospel, the risen Jesus had summarized the message to be proclaimed after his resurrection as 'repentance for the forgiveness of sins' (Lk. 24:47). Peter, in two early sermons in Acts, had called on Jewish audiences to 'repent and be baptised, each of you, in the name of Jesus Christ for the forgiveness of your sins' (2:38), and to 'repent, therefore, and turn, so that your sins may be blotted out' (3:19; cf. v 26b). Not surprisingly, the message of the Lukan Paul is consistent with the message of salvation proclaimed throughout LukeActs as a whole. And because Christian 'evangelization' in Luke-Acts begins with John and his call to repentance (cf. $\varepsilon v \alpha \gamma \gamma \varepsilon \lambda i \zeta \varepsilon \sigma \theta \alpha$ in Luke 3:18 and 16:16), the echo of John in Acts 20:21 is natural and appropriate.

Still, there are two distinctly Pauline touches in the summary. First, if 'repentance toward God' recalls John the Baptist's ministry as traditionally understood (cf. 'baptism of repentance' in Mk 1:4//Lk. 3:3; Acts 13:24, 19:4a), the accompanying phrase, 'faith in our Lord Jesus', sums up not only Paul's own ministry, but that of John as Paul had interpreted it in his two earlier pronouncements (Acts 13:25, 19:4b). Second, Paul applies to himself in the context virtually the same expression he had used earlier of John. In 13:25 he had quoted a pronouncement made 'as John was fulfilling his course' ( $\dot{\omega} \delta \dot{\delta}$

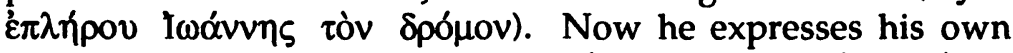

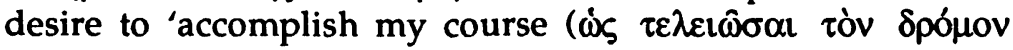
$\mu \mathrm{OV})$, and the ministry I received from the Lord Jesus' (20:24). A related saying is independently attributed to Paul in 2 Tim 4:7: 'I have fought the good fight, I have finished the course (ròv Spópov $\tau \varepsilon \tau \dot{\varepsilon} \lambda \varepsilon \kappa \alpha)$, I have kept the faith'. Possibly this similarity of phrase helps explain Tertullian's otherwise 
strange reference to Paul's martyrdom in Rome, 'where Paul was crowned with the "departure" (i.e., death) of John'.10

The indebtedness of the Lukan Paul to John the Baptist is even more evident in the speech before Herod Agrippa in Acts 26:19-20. Paul's extended account of his early life and his vision on the road to Damascus concludes with a rehearsal of the risen Christ's promise to him to 'rescue you from your own people and from the Gentiles' and a commission 'to open their eyes and turn ( $\tau 0 \hat{v} \dot{\varepsilon} \pi \iota \tau \rho \dot{\phi} \phi \alpha)$ ) them from darkness to light and from the authority of Satan to God, so that they may receive forgiveness of sins and a place among those who are sanctified by faith in me' (vv. 17-18). Paul then tells the king that in obedience to this vision he preached 'first to those in Damascus, and then to Jerusalem and the entire region of Judea, and the Gentiles, that they should repent and turn to God

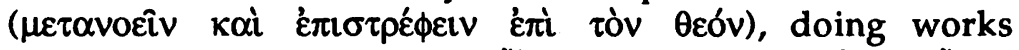

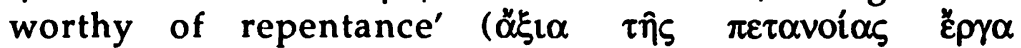
$\pi p \alpha ́ \sigma \sigma o v \tau \alpha \varsigma$, v. 20). The striking phrase here is the last one, echoing as it does John's appeal in Luke 3:8 to 'make fruits,

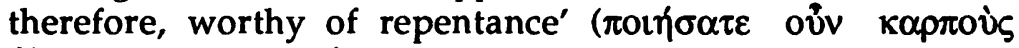

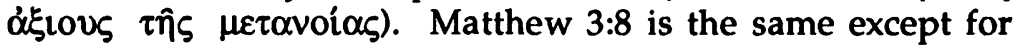

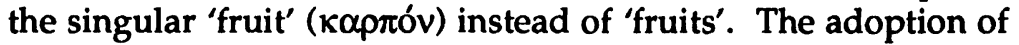
this terminology by the Lukan Paul to describe his own ministry shows his acquaintance not only with Markan traditions about John the Baptist (i.e., his baptizing activity and proclamation of the Coming One; cf. Acts 13:24-25 and 19:4), but with the socalled ' $Q$ ' material as well (i.e. John's call to repentance, summarized almost identically in Mt. 3:7-10 and Lk. 3:7-9).

The picture that emerges from these texts is of a Christian missionary who saw himself doing for Jew and Gentile alike what John the Baptist had done for the Jews: i.e., calling them to repent and believe in Jesus. Paul's pronouncement in Acts 20:21 cannot be divided up as if 'repentance toward God' were for the Jews and 'faith in our Lord

\footnotetext{
${ }^{10}$ 'Ubi Paulus Ioannis exitu coronatur' (Praescr. 36.3, in F. Oehler, Tertulliani Quae Supersunt Omnia (Leipzig, Weigel 1854) 2.34). Cf. the use of exitum for the death of Jesus in certain old Latin manuscripts of Luke 9:31. J. A. T. Robinson, citing the passage from Tertullian in another connection in Redating the New Testament (London, SCM 1976) 223, notes that 'in Tertullian "exitus" regularly means "death".'
} 
Jesus' for the Gentiles - or the other way around. Repentance, or 'turning to God', was necessary for all the Jews from Damascus to Judea and Jerusalem, and for the Gentiles too. All had the same responsibility to do works worthy of that repentance (Acts 26:20). And all had the same responsibility to believe, for Paul understood John's proclamation as an invitation to believe in Jesus. Faith and repentance are inseparable for Paul in the Book of Acts, and because they are, Paul sees his own ministry as a kind of extension of John's, beyond the Judean desert to the entire Mediterranean world.

Obviously, there were limitations to John's usefulness as a model for the Lukan Paul, though these limitations are perhaps more significant to us than they would have been to Paul himself. The most obvious difference between the two men is that Jesus was future, not past or present, to John the Baptist. Paul does not even mention the fact that John baptised Jesus. As Paul saw it, Jesus was not John's contemporary, but 'the one coming after' John (Acts 19:4; cf. 13:25), while for Paul himself the Coming One had already come and been raised from the dead. None of the analogies between Paul and John the Baptist in Acts should be allowed to obscure the centrality of Jesus' resurrection in the message of Paul (see, e.g., Acts 13:30-37; 17:3, $18,31 ; 23: 6-8 ; 26: 8) .{ }^{11}$ Although Paul and his companions baptised some of their converts (Acts 16:15, 33; 18:8; 19:5), he makes nothing of his role as baptiser. Nor does the Lukan Paul, even in Acts 19:1-7, make anything of the fact that John had promised the coming of the Spirit. To Paul, John the Baptist is a witness to Jesus, not to the Holy Spirit, or to a future baptism in the Spirit. Paul's indebtedness to John in the Book of Acts is largely confined to a strong emphasis on repentance, which Paul equates with faith in Jesus, and (in one instance) the works that repentance produces.

It could be argued, moreover, that even these similarities are of Luke's making. If Luke was capable of drawing analogies between John the Baptist's proclamation

\footnotetext{
${ }^{11}$ Note, however, that the risen Jesus in at least one of Paul's speeches is still the Coming One, for God has 'set a day on which he is going to judge the world in righteousness, by a man whom he has appointed, and he has given proof of this to all by raising him from the dead' (Acts 17:31).'
} 
and that of Peter at Pentecost, ${ }^{12}$ it would not be surprising if he were to do the same in relation to Paul's ministry. If John indeed 'preached the gospel', as Luke thought (Lk. 3:18, 16:16), echoes of his preaching in the course of the early Christian mission are to be expected. Still, nowhere are these echoes quite so evident as in words attributed to Paul. No one in Acts except Paul picks up such a phrase as 'doing works worthy of repentance'. No one but Paul ventures to quote John or interpret his words. ${ }^{13}$ Yet it would be difficult to argue that Luke has consciously set out to portray Paul as another John the Baptist, or even to call attention to the similarities between the two men. The parallels seem to belong to Luke's tradition, not to any redactional purpose that Luke brings to the tradition. Is it not possible that the 'tradition' in this case consisted of utterances remembered by some of Paul's hearers as characteristic of his preaching? It is likely - unless one wishes to argue that the Book of Acts is familiar with Paul's letters - that this is the case with the Lukan Paul's reference to justification in Acts $13: 39$, and there is no reason why it may not be true of his interpretation of John as well. Whether it is or not depends in part on the evidence of the letters. If the sayings of Jesus are seldom mentioned in Paul's letters, we can hardly expect to find very many echoes of the words or deeds of John, and in fact we do not. Yet the few we do find should not go unnoticed.

\section{John the Baptist and the Letters of Paul.}

The case does not look promising on the face of it. Paul in his letters is even less a baptizer than Paul in the Book of Acts. 'I am thankful', he tells the Corinthians, 'that I baptised none of you except Crispus and Gaius, lest anyone should say you were baptised in my name. . .for Christ did not send me to baptize, but to preach the gospel' (1 Cor. 1:14-15, 17). The terms 'repent'

\footnotetext{
${ }^{12}$ I.e., the responses of John's audience and Peter's are the same: 'What shall we do?' (Lk. 3:10, 12, 14; cf. Acts 2:37), and in both instances Luke is careful to point out that more was said than what he has explicitly quoted (Lk. 3:18; cf. Acts 2:40).

${ }^{13}$ Again, the only possible exception is the risen Jesus in Acts 1:5, cited by Peter in 11:16 (cf. n. 2). Jesus' pronouncement could be read as a restatement (from his own perspective) of John's words in Mk 1:8 (cf. Mt. 3:11//Lk. 3:16; Jn 1:26, 33). Yet Luke presents it unmistakably as an independent word of Jesus. All it actually says of John is that he 'baptised in water.'
} 
and 'repentance', so important to the Lukan Paul, all but disappear in Paul's letters. When they do occur, they are used (with one notable exception) not of the acceptance of the Christian message by Jews or Gentiles, but of sorrow for sins and a return to right living among those already in the Christian

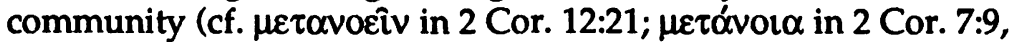
10, and 2 Tim. 2:25). The single exception, Romans 2:4, is worthy of attention, however, along with two other pieces of evidence, 1 Thessalonians 1:9-10, and the discussion in Galatians and Romans of what it means to be a child of Abraham.

1. 1 Thessalonians 1:9-10. Paul's first summary of the Christian experience he intended to foster among the Gentiles is found in his introductory praise of the believers at Thessalonica. He claims to have heard from other churches how you turned to

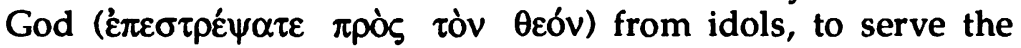
living and true God, and to wait for his Son from heaven, whom he raised from the dead, Jesus, who delivers us from the wrath to come'. The summary recalls Paul's messages to Gentiles in the Book of Acts; e.g., the phrase, 'turned to God', echoes the sermon at Lystra in Acts 14:15, while the simultaneous accent on Jesus' past resurrection and on future wrath or judgment parallels the speech to the Athenian philosophers in Acts 17:31. The idea of 'repentance', if not the actual terminology, is evident in the passage.

More to the point, the notion of deliverance from 'the

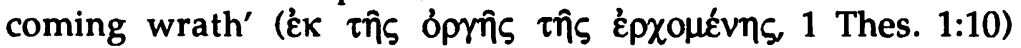
recalls John's sarcastic question, 'Who has warned you to flee

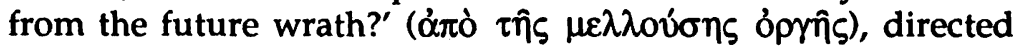
at the multitudes according to Luke 3:7, and at the Pharisees and Sadducees according to Matthew 3:7. Paul, like John the Baptist, is concerned about avoiding the wrath of God that he sees coming against the world (cf. Col. 3:6, Eph. 5:6). Whatever else it may be, Christian salvation to Paul is deliverance from that future divine wrath (cf. 1 Thes. 5:9, 'for God has not destined us to wrath, but to gain salvation through Jesus Christ our Lord'; also Rom 5:9, 'through him we shall be saved from the wrath'). Paul even follows John in viewing Jesus himself as One still to come (as John did according to Acts 19:4). Paul reminds the Thessalonians not that they have 'believed' in 


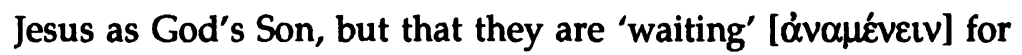
him from heaven The sole difference between Paul and John is that for Paul the future coming of Jesus and salvation from the wrath is now guaranteed by Jesus' resurrection in the past.

2. Romans 2:4. Paul's most sustained development of the theme of wrath to come is found in Romans, especially the section near the beginning where he finds the whole world guilty before God (Rom. 1:18-3:20). Paul begins by announcing that 'God's wrath' (ỏpyì $\theta \varepsilon 0 \hat{)})$, like God's justice, is now 'being revealed'

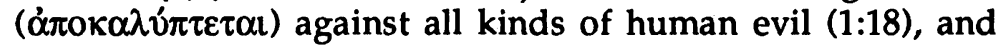
later makes a comparable statement about 'the judgment of God' ( against all who do such things' (2:2; i.e. the things enumerated in 1:18-32). In the manner of John the Baptist, he then asks, 'Do you suppose, whoever you are (lit., ' $\mathrm{O}$ man') who judges those who do such things while you do the same, that you will escape

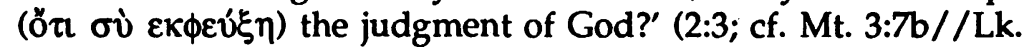
3:7b). 'The accent has by now shifted to a primarily future wrath or judgment. Paul continues: 'Or do you despise the wealth of his kindliness and forbearance and patience,

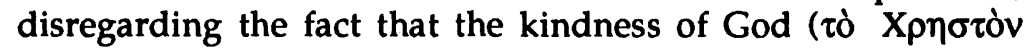

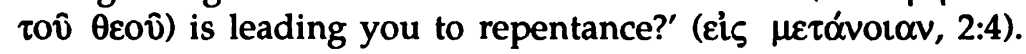
His verdict is that 'in keeping with your stubbornness and your

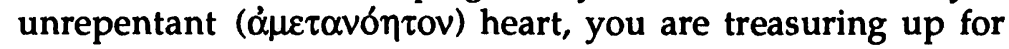
yourself wrath in the day of wrath, and of the revealing of the

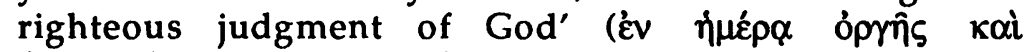

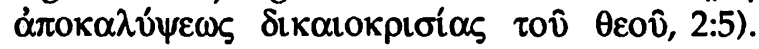

Nowhere in his letters is Paul so close to John the Baptist as here, especially if (as most commentators assume) he has in mind the pretensions of Jews who claimed to live by the law. ${ }^{14}$ Yet surprisingly, he goes on to speak of 'works' as the

\footnotetext{
${ }^{14}$ See, e.g., J.D.G. Dunn, Romans 1-8 Word Biblical Commentary 38A (Dallas, Word Books 1988), 79-80. Dunn also observes that repentance for Paul was normally 'too much bound up with the accepted understanding of God's covenant goodness, so that Paul prefers the more widely embracing concept of "faith" as one through which he can develop his (Christian) reinterpretation of the covenant more readily. . ' Here, however, Paul uses 'the more "Jewish" language of goodness and repentance . . .rather than the more distinctively "Christian" language of grace. . and faith' (82; cf. 206-07, where Dunn makes a similar point even with reference to the phrase, 'forgiveness of sins'). The difference, according to Dunn, stems from Paul's desire 'to turn one of the Jewish
} 
basis of divine judgment on the coming 'day of wrath'. God will

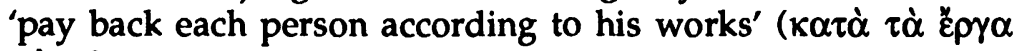

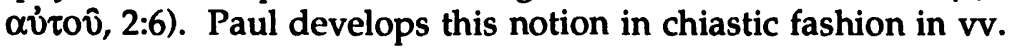
7-11: 'Eternal life to those who, by the persistence of a good

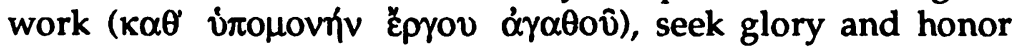
and immortality, but wrath and anger (opyri kai $\left.\theta u \mu \delta \delta^{\prime}\right)$ to those who, out of selfishness, disobey the truth and obey unrighteousness. Trouble and distress on every human soul who

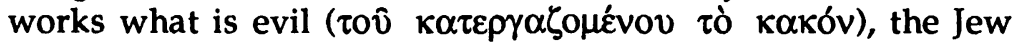
first and then the Greek; glory and honor and peace for

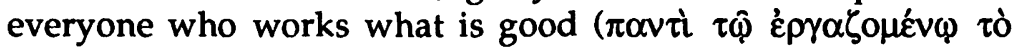
$\dot{\alpha} \gamma \alpha \theta \delta$ v), for the Jew first and then the Greek. For there is no partiality with God.'

Because of the apparent conflict between this passage and the classic understanding of Paul's doctrine of justification by grace through faith, some interpreters have ignored the passage while others have discussed it at very great length. C.E.B. Cranfield considers no less than ten possible interpretations, ${ }^{15}$ but if the similarities between Paul and John the Baptist are brought to bear on this text, yet another option presents itself. The mention of 'repentance' (2:4) and the warning of the 'day of wrath' (v. 5) seem to have led Paul into his reflection on judgment according to 'works' (v. 6). Here the Paul of Romans is fully in line with the Paul of Acts 26:20, who called on Jew and Gentile alike to 'repent and turn to God, doing works worthy of repentance'. He is also fully in line with John the Baptist (according to the so-called ' $Q$ ' tradition) who called on his Jewish hearers to 'make fruit (or, fruits), therefore, worthy of repentance' (Mt. 3:8//Lk. 3:8). Is it not possible that Paul in Romans 2:7-11 is simply enlarging, in the manner of John, on his call to a hypothetical Jewish listener to repent (vv. 4-5)? As the chiasm of vv. 7-11 unfolds, Paul draws Jew and

interlocutor's key beliefs against him' (82), yet it is simply one instance of Paul's use of 'sub-Christian' (or at least 'sub-Pauline') vocabulary throughout Rom. 1:18-3:20, and at certain other points in the letter (e.g., 7:7-25, ch.11). This is a phenomenon in need of further study.

${ }_{15} A$ Critical and Exegetical Commentary on the Epistle to the Romans., ICC (Edinburgh, T. \& T. Clark 1985) 1.151-52; see also K.R. Snodgrass, 'Justification by Grace - to the Doers: An Analysis of the Place of Romans 2 in the Theology of Paul', NTS 32.1 (1986), 72-93, and the survey of interpretations found there (73-75). 
Greek alike into his implicit invitation, just as in Acts 26:20 his ministry of repentance was said to embrace Damascus, Jerusalem, Judea, and the Gentiles. It is doubtful that either John the Baptist or Paul would have made any sharp distinction between 'works worthy of repentance' and repentance itself.

The link between Paul's thought and the Baptist's thus yields an interpretation of Romans 2:6-11 rather close to that of Cranfield, ${ }^{16}$ but puts it on a new basis, with 'repentance' (in the tradition of John) as the presupposition of Pauline 'faith', and with repentance rather than faith as the explicit point of departure. ${ }^{17}$ With this passage as a starting point, it is possible to raise the further question-and I will do no more than raise it-of Paul's possible indebtedness to John for the notion that Gentile Christians are 'children of Abraham'. When John the Baptist told his hearers to 'make fruit worthy of repentance', he added, 'and do not presume [Luke: begin] to say in yourselves, "We have Abraham as father," for I tell you that from these stones God is able to raise up children to Abraham' (Mt. 3:9//Lk. 3:8b). The notion that being a child of Abraham depends on repentance, not birth, finds an echo in the Gospel tradition in the teaching attributed to Jesus in John 8:3740 , where a child of Abraham is one who does 'the works of Abraham' (v. 39) by receiving Jesus as God's messenger (v. 40). Yet most students of the Gospels would agree that the idea is more firmly rooted in John the Baptist's words from ' $Q$ ' than in these words of Jesus from the fourth Gospel. When Paul develops in Galatians the idea that 'those who are of faith are sons of Abraham' (Gal. 3:7), and that 'If you are Christ's, then you are Abraham's seed and heirs according to the promise' (Gal.3:29), or in Romans the notion that Abraham is the father of all who believe but are uncircumcised, that righteousness might be credited to them' (Rom 4:11b), few would argue that he is drawing on the words of Jesus recorded in John 8. The

\footnotetext{
${ }^{16}$ Cranfield's view is that 'works' in this passage refers to 'each man's conduct as the expression either of faith or unbelief' (151-52).

${ }^{17}$ Note that Paul's classic terminology of 'faith' and 'believe' occurs only twice between Rom 1:18 and 3:20, and then not in relation to righteousness or salvation

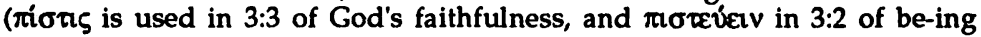
'entrusted' with the Scriptures).
} 
possibility that he is drawing on the sayings of John the Baptist about repentance preserved in Matthew and Luke, however, is more difficult to rule out, especially in light of Paul's preaching in Acts and certain hints in 1 Thessalonians and Romans of his dependence on John.

\section{v. Conclusion}

In this article I have consciously violated a major rule of Pauline research by beginning with the Lukan portrait of Paul in the Book of Acts, and using conclusions drawn from that study to interpret certain problematic passages in Paul's letters. But are the results so implausible? There is little evidence to suggest that the subtle links between John the Baptist and Paul in Acts are a deliberate Lukan construction. If Luke had wanted to make that connection, he could done so on a far wider front and in a more obvious way. More likely, Luke has preserved some authentic echoes of Paul's missionary preaching, including his citation and interpretation of John the Baptist, as well as his self-assessment in language reminiscent of John's. If so, it is not so surprising to find similar phenomena, at least occasionally, in his letters.

No one will argue that John the Baptist was the major influence on Paul's life and thought. Paul's language is saturated with the reality of the Holy Spirit and the risen Christ in a way that John the Baptist's never could have been. Yet John seems to have been for Paul a precedent, his only role model other than Jesus himself for the preaching of 'eschatological repentance' to Israel and the Gentiles. He was a more appropriate role model than Jesus precisely because he was not Jesus, but (like Paul) someone who called people to believe in Jesus (Acts 19:4). Paul's self-identification with John the Baptist may have served as a check against mysticism, and a protection against the danger of identifying his own mind and consciousness too closely with that of Jesus (cf., e.g., Gal. 2:20a, I no longer live, but Christ lives in me'). If Jesus was for Paul the Risen One, he was also still the Coming One, even as he had been for John. If the Spirit represented for Paul the 'already' of Christian experience, John and his remembered words may have represented the 'not yet', and the continuing need to 'do works worthy of repentance' and to 'escape the 
wrath to come'. To claim that John the Baptist is the key to understanding the mind of Paul is to claim far too much, but there is evidence at least to support the more modest conclusion that the two are by no means an odd couple. 